BEduManageRs Journal

Borneo Educational Management and Research Journal, Vol.2, No.1, 2021

ISSN: 2747-0504

\title{
Manajemen Mutu Terpadu Di SMK Negeri 7 Samarinda
}

\author{
Muhammad Yusuf ${ }^{1}$, Muh. Amir $\mathbf{M}^{2}$, Hasbi Sjamsir ${ }^{3}$ \\ Universitas Mulawarman \\ e-mail: doktormp@fkip.unmul.ac.id, sjamsirhasbi@yahoo.com, nurergaamir@yahoo.com
}

\begin{abstract}
To face of an increasingly strong and competitive Globalization Era, implementing MMT at schools is very important for the long-term success of school organizations and is a source of excellence in order to create performance and productivity towards achieving continuous Quality Management. The purpose of this study was to determine: (1) the application of MMT at Samarinda State Vocational High School in an effort to improve school quality management, (2) the level of achievement of Integrated Quality Management (MMT) at Samarinda State Vocational School in an effort to improve school quality management, (3) which was an obstacle to Integrated Quality Management (MMT) at Samarinda State Vocational High School in an effort to improve school quality management. This study uses a qualitative descriptive design. The interview guide is used to explore information about the application, level of achievement and factors that become obstacles to Integrated Quality Management (MMT) at SMK Negeri 7 Samarinda. The results showed that: (1) the application of MMT to Samarinda State Vocational High School seven had been implemented and went well, (2) the level of achievement of MMT at Vocational High School seven had shown good results with increasing students, increasing educator HR, good quality of facilities and infrastructure, as well as a conducive work and learning environment, (3) Factors that become obstacles to the application of MMT to Vocational High School seven are the use of technology that is not maximized for some teachers, there are still some internal parties lacking commitment in quality assurance, learning methods, and lack of discipline of teachers in teaching. It can be concluded that the results of the research on the implementation of MMT in Samarinda State Vocational High School 7 Kalimantan through the implementation of MMT found an increase in performance and school quality assurance.
\end{abstract}

Keywords: Integrated Quality Management, Integrated Quality Management Implementation, School.

\section{PENDAHULUAN}

Di era globalisasi saat ini, pergaulan antara bangsa telah menjadi dunia tanpa batas, baik dalam bentuk batas geografis, politik ekonomi maupun sosial budaya. Tidak satupun negara di belahan bumi ini yang tidak saling berhubungan secara timbal balik antara satu dengan yang lainnya dalam upaya posisi dalam konteks hubungan dan kerjasama antar negara, diperlukan keunggulan kompetitif sumber daya manusia. Jika tidak memiliki keunggulan kompetitif dengan daya tawar yang diperhitungkan maka hubungan dan kerjasama tersebut hanya akan terjadi saling mendominasi, bukan saling memerlukan.

Sebagai salah satu yang tercepat dalam perkembangan ekonomi sebagai negara berkembang, Indonesia berkembang dengan 5,27 GDP (Gross Domestic Product). Diantaranya didominasi oleh industri Jasa. Menurut Indonesia Badan Koordinasi Penanaman Modal/BKPM (2013), permintaan kelas menengah Indonesia lebih tinggi permintaan untuk pelayanan publik. Ini menunjukkan sebagaian besar pekerjaan yang dihasilkan oleh layanan yang jumlah pekerja di 
BEduManageRs Journal

Borneo Educational Management and Research Journal, Vol.2, No.1, 2021

ISSN: 2747-0504

sektor jasa mengalami pertumbuhan. Angka ini setiap tahun. Sekolah saat ini juga dibebani mencapai $6,49 \%$ lebih dari sektor lain sampai Agustus 2013.

Namun nasib pendidikan Indonesia tak semulus pertumbuhan ekonomi yang dibangunnya. Menurut Larada yang dikutip Tribunnews.com anggaran 20 persen untuk pendidikan dari total APBN, belum mampu dimanfaatkan secara maksimal untuk kepentingan pendidikan. Sehingga wajar jika di daerah-daerah masih banyak disaksikan kondisi fisik sekolah yang sangat memprihatinkan baik tingkat dasar hingga menengah, adanya Bantuan Operasional Sekolah (BOS) dan kampanye sekolah gratis, bukan menambah kualitas dan mutu peserta didik. Melainkan justru memperburuk jaminan kualitas pendidikan ke depan. Di sisi lain imbuhnya, peningkatan kualitas guru sejalan dengan tuntutan zaman dan perubahan kebutuhan tenaga kerja, masih jauh dari harapan dan target RPJP di bidang pendidikan. Kemudian perubahan kurikulum yang hingga kini masih menimbulkan kontroversi, sebagai bukti bahwa Kementerian Pendidikan dan Kebudayaan tidak pernah merencanakan Sistem Pendidikan Nasional secara mapan dan terintegrasi.

Bagi sekolah sebagai lembaga pendidikan kemudian dibebani dengan faktor persaingan yang lebih berat dalam mempertahankan eksistensi sekolah baik secara akademis maupun non akademis. Menurut data Kementerian Koordinator Bidang Kesejahteraan Rakyat, terdapat perkembangan jumlah sekolah yang signifikan, di Indonesia terdapat 9.315 Sekolah Menengah Kejuruan (SMK) pada tahun 2005/2006, 9.892 SMK pada tahun 2006/2007 dan 10.239 pada tahun 2007/2008 yang berarti terdapat rata-rata pertumbuhan hingga 347 SMK sederajat baik negeri maupun swasta setiap tahunnya di Indonesia dari data yang sama untuk daerah Kalimantan Timur saja terdapat rata-rata pertumbuhan SMK sederajat hingga 15 SMK dengan status atau predikat baik yang diberikan oleh masyarakat maupun dengan pembuktian akan prestasi mereka, embel-embel seperti sekolah bertaraf internasional, sekolah dengan standar ISO atau sekolah unggulan merupakan status yang sanggup digunakan untuk menarik perhatian calon siswa. Pasalnya sekolah yang saat ini tidak hanya berdasarkan pada teritorial saja melainkan persaingan datang juga dari berdirinya sekolahsekolah swasta yang umumnya dibuat dengan sistem manajemen yang diusahakan lebih baik untuk bertahan secara ekonomi dibandingkan sekolah negeri yang telah mendapat bantuan dari pemerintah. Tentang persaingan manajemen adalah bagaimana mengembangkan pelanggan yang loyal demi keunggulan dalam kompetisi. Akibatnya untuk memasarkan pendidikan, diperlukan Total Quality Management (TQM) atau Manajemen Mutu Terpadu. Berdasarkan Liao, Chang, dan $\mathrm{Wu}$ (2010) bahwa berpikir tentang TQM tidak hanya untuk manajemen manufaktur dan jasa manajemen tetapi manajemen layanan pendidikan. Dengan memahami TQM dalam pendidikan maka sebuah institusi akan dapat untuk memenuhi kebutuhan dan keinginan para pemangku kepentingan.

Pengelolaan pelayanan adalah salah satu cara untuk meningkatkan kualitas pelayanan di bidang pendidikan (TQM dalam pendidikan). Mahapatra dan Khan dalam Magdalena dan Junita menjelaskan kualitas dalam pendidikan adalah cara terbaik untuk melayani dan menarik siswa. Banwet dan Datta dalam Magdalena dan Junita mengutip definisi kualitas dari ISO (9004-2) dan ISO (1991) sebagai kemampuan layanan untuk memuaskan pelanggan. Jika organisasi pendidikan melayani mahasiswa dengan kualitas maka ia memiliki keunggulan kompetitif karena kepuasan pelanggan akan tercapai. Kepuasan pelanggan sebagai faktor utama untuk menciptakan loyalitas. Karena itu, pemahaman tentang mengelola 
BEduManageRs Journal

Borneo Educational Management and Research Journal, Vol.2, No.1, 2021

ISSN: 2747-0504

pelayanan pendidikan memberikan banyak keuntungan bagi lembaga.

\section{KAJIAN TEORI}

Istilah Manajemen Mutu Terpadu (MMT) sebenarnya merupakan terjemahan yang paling dianggap pas dari istilah Total Quality Management (TMQ) TMQ adalah suatu filosofi suatu peningkatan yang berkelanjutan, yang dapat dijadikan alat praktis oleh lembaga pendidikan dalam memenuhi kebutuhan, keinginan serta harapan pelanggan sekarang dan dimasa yang akan datang. Dalam kaitan ini, seluruh bagian dan sistem lembaga harus saling mendukung dan saling melengkapi. Keberhasilan unit-unit tersebut mempengaruhi keberhasilan organisasi secara keseluruhan.

Definisi MMT (TQM), seperti definisi-definisi lainnya, berbeda-beda tergantung sudut pandang orang yang mendefinisikannya. Definisi Manajemen Mutu Terpadu Pendidikan (MMTP) menurut West- Burnham (1997) ialah semua fungsi dari organisasi sekolah ke dalarn falsafah holistis yang dibangun berdasarkan konsep mutu, kerja tim, produktivitas, dan prestasi, serta kepuasan pelanggan. Sedangkan MMTP menurut Sallis (2003) ialah menciptakan budaya mutu di mana tujuan setiap anggota ingin menyenangkan pelanggannya, dan di mana struktur organisasinya mengizinkan untuk mereka berbuat seperti itu.

Definisi mengenai MMTP ialah suatu sistem manajemen yang menyangkut mutu sebagai strategi usaha dan berorientasi pada kepuasan pelanggan dengan melibatkan seluruh anggota organisasi.

Berdasarkan Mt. Edgecumbe mengimplementasikan prinsip-prinsip TQM menurut versi adaptasi "14 poin Deming" untuk kualitas di dalam organisasi. Poin-poin di bawah ini direproduksi seluruhnya dan menggunakan jenis huruf tebal untuk ide-ide kuncinya.
1. .Menciptakan dan memelihara ketepatan tujuan untuk meningkatkan layanan terhadap siswa dan sekolah.

2. Menganut filosofi baru. Manajemen sekolah harus menyadari tantangan, harus mempelajari tanggung jawab mereka, dan mengambil kepemimpinan untuk berubah.

3. Bekerja untuk menghapuskan angka dan pengaruh-pengaruh berbahaya dari penilaian terhadap siswa. Berfokus pada proses pembelajaran, bukan proses penilaian terhadap siswa.

4. Menghentikan ketergantungan pada ujian untuk mencapai mutu. Menyediakan pengalaman pembelajaran yang dapat menciptakan kinerja yang berkualitas; pengalaman pembelajaran yang dapat memotivasi kreativitas serta eksperimentasi.

5. Bekerja dengan institusi-institusi pendidikan tempat siswa berada.

6. Terus-menerus dan selalu memperbaiki sistem untuk meningkatkan layanan terhadap siswa dan pendidikan dalam rangka meningkatkan mutu dan produktivitas dalam kehidupan pribadi dan masyarakat.

7. Terus-menerus melembagakan pelatihan dalam jabatan bagi siswa, guru, staf khusus dan administrator, bagi semua orang yang berhubungan dengan organisasi kemanusiaan atau masyarakat.

8. Melembagakan kepemimpinan.

9. Mengusir ketakutan, supaya setiap guru dan staf sekolah bekerja secara efektif untuk suatu sistem sekolah.

10. Mematahkan rintangan di antara bagianbagian. Orang di bagian pengajaran, pendidikan khusus, akuntansi, kantin, administrasi, pengembangan kurikulum dan penelitian harus bekerja sebagai suatu tim.

11. Menghapus slogan, pernyataan, dan target bagi guru dan siswa yang meminta kinerja 
BEduManageRs Journal

Borneo Educational Management and Research Journal, Vol.2, No.1, 2021

ISSN: 2747-0504

yang sempurna dan tingkat produktivitas yang baru.

12. Menghapus standar-standar pekerjaan (quota) guru dan siswa (misalnya, nilai ujian naik 10\%; angka putus sekolah turun 15\%).

13. suatu program pendidikan dan perbaikan diri yang kuat bagi setiap orang. Kemampuan guru dan manajemen sekolah ditingkatkan.

14. Menempatkan setiap orang dalam masyarakat untuk bekerja melakukan transformasi. Transformasi merupakan pekerjaan dari setiap stakeholders sekolah.

masalah-masalah yang menyebabkan MMTP tidak dapat diterapkan, yaitu karena usaha dilakukan setengah hati dan kesalahan lainnya, meliputi (1) delegasi dan kepemimpinan yang tidak baik dari manajemen senior, (2) tim mania, (3) proses pcnyebarluasan, (4) pendekatan yang terbatas (sempit) dan dogmatis, (5) harapan yang terlalu berlebihan (tidak realistis), dan pemberdayaan karyawan yang bersifat prematur.

MMTP akan sukses diterapkan pada lembaga pendidikan jika manajer pendidikan melakukan SAL (Seharusnya yang Anda Lakukan), yaitu

1) pahami: filosofi, visi, misi, aksi, kebutuhan pelanggan, dan keunikan karyawan;

2) ciptakan: proses yang efisien, budaya kerja yang kondusif, dan tim kerja yang solid.

3) galakkan: pencatatan data, usaha perbaikan, dan semangat kerja.

4) kembangkan: diri sendiri, bawahan, dan rekanan.

5) dapatkan: kesamaan persepsi, komitmen atasan, teman seleve 1, dan bawahan.

6) terapkan: gaya kepemimpinan partisipatif (STMB, 1999).

Sebaliknya, Jangan Anda Lakukan (JAL) adalah :

1) berpikir negatif, berperilaku "bos"

2) statis

3) resisten terbadap perubaban.

4) mengabaikan pendapat/kritik.

5) beranggapan hasil kerja adalah basil Anda sendiri.
6) Sangat subjektif.

7) Tidak adil.

8) Tidak jujur.

\section{METODOLOGI PENELITIAN}

Penelitian ini bertujuan mendeskripsikan, menganalisis dan memperbaharui kualitas manajemen dengan inovasi manajemen pendidikan demi mencapai perkembangan kualitas. Penelitian ini merupakan penelitian kualitatif. Penelitian kualitatif adalah metode penelitian yang berlandaskan pada filsafat postpositivisme, digunakan untuk meneliti pada kondisi obyek yang alamiah, (sebagai lawannya adalah eksperimen) dimana peneliti adalah sebagai instrument kunci, teknik pengumpulan data dilakukan secara triangulasi (gabungan), analisis data bersifat induktif/kualitatif, dan hasil penelitian kualitatif lebih menekankan makna dari pada generalisasi.

Sedangkan penelitian deskriptif merupakan bentuk penelitian yang paling dasar, yakni mendeskriptikan atau menggambarkan fenomenafenomena yang ada, baik yang alamiah maupun yang direkayasa.

Penelitian deskriptif memiliki beberapa varian, tetapi pada penelitian ini menekankan pada studi kaasus. Studi kasus yaitu metode untuk menghimpun dan menganalisis data berkenaan dengan sesuatu kasus.

\section{HASIL DAN PEMBAHASAN}

\section{Penerepan Manajemen Mutu Terpadu di SMK Negeri 7 Samarinda}

Dalam hal ini peneliti mengadakan observasi apakah standar mutu sistem yang diterapkan di SMK Negeri 7 Samarinda sudah diterapkan dan dilaksanakan dengan baik atau belum sehingga dapat dilihat dari banyak tidaknya peminat dari masyarakat disekitar dan masyarakat luas yang mempercayai untuk menyekolahkan anaknya di SMK Negeri 7 Samarinda.

Dalam pelaksanaan proses pembelajaran di SMK Negeri 7 Samarinda digunakan berbagai 
BEduManageRs Journal

Borneo Educational Management and Research Journal, Vol.2, No.1, 2021

ISSN: 2747-0504

pendekatan, strategi, dan teknik yang menantang, agar dapat mengkondisikan peserta didik belajar untuk berpikir kritis, bereksplorasi, berkreasi, dan bereksperimen, dengan memanfaatkan berbagai sumber ajar. Pendekatan metode pembelajaran secara bertahap diarahkan agar berpusat kepada peserta didik (student centered learning), dengan kondisi pembelajaran yang mendorong peserta didik untuk belajar mandiri dan berkelompok.

\section{Tingkat Ketercapaian Manajemen Mutu}

Terpadu pada SMK Negeri 7 Samarinda

Untuk membandingkan antara sistem manajemen mutu dengan tingkat ketercapaian di SMK Negeri 7 Samarinda adalah Pendekatan sistem manajemen mutu yang diberikan dalam kelompok standar mutu dan model unggulan organisasi didasarkan pada prinsip yang sama antara lain :

a) Memungkinkan organisasi mengetahui kekuatan dan kelemahannya.

b) Berisi ketentuan untuk pencapaian terhadap model generik.

c) Memberi dasar bagi perbaikan berlanjut.

d) Berisi ketentuan untuk pengakuan eksternal.

3. Faktor Yang Menjadi Penghambat Dalam Implementasi Sistem Manajemen Mutu di SMK Negeri 7 Samarinda

a) Faktor Penghambat Implementasi Sistem Manajemen Mutu

b) Somatis

c) Auditori

d) Visual

e) Kendala peningkatan mutu pendidikan

\section{PEMBAHASAN}

\section{Penerapan Manjemen Mutu Terpadu di SMK Negeri 7 Samarinda}

Berdasarkan hasil penelitian yang dilakukan, peneliti dapat menyimpulkan bahwa standar mutu dalam melaksanakan proses belajar mengajar yang diterapkan di SMK Negeri 7 yaitu:

1) Guru harus disiplin dalam melaksanakan pembelajaran di kelas.

2) Beban mengajar maksimal guru diatur sedemikian rupa sehingga memungkinkan terselenggarakannya pembelajaran yang efektif.

3) Jumlah siswa per kelas disesuaikan.

4) Siswa terlibat secara aktif sehingga tercipta interaksi yang mendukung pembelajaran.

5) Guru harus menjadi pribadi yang patut diteladani secara pedagogi, personal, sosial, dan profesional dalam proses pembelajaran.

6) Guru harus berperan sebagai fasilitator yang mendorong kemadirian belajar.

7) Metode pembelajaran yang diterapkan harus dapat mengembangkan pembelajar semaksimal mungkin.

8) Sarana dan prasarana pembelajaran harus dimanfaatkan secara optimal.

9) Metode pembelajaran harus mengarahkan siswa untuk belajar mandiri maupun kelompok.

10) Guru mampu mengembangkan dan menggunakan berbagai media pengajaran.

11) Sumber belajar bisa diakses oleh pihakpihak yang berkepentingan.

Dalam kesimpulan diatas teori mutu yang dicetuskan oleh Deming ini dikembangkan untuk menghubungkan antara operasi dengan kebutuhan pelanggan dan memfokuskan sumber daya semua bagian dalam organisasi (riset, desain, operasi, dan pemasaran) secara terpadu dan sinergi untuk memenuhi kebutuhan. Siklus Deming adalah mode perbaikan berkesinambungan yang dikembangkan oleh W. Edward Deming yang terdiri atas empat komponen sebagai berikut:

1) Mengembangkan rencana perbaikan (Plan). Ini merupakan langkah setelah dilakukan pengujian ide perbaikan masalah. Rencana perbaikan disusun berdasarkan prinsip 5-W (what, why, who, when, dan where) dan $1 \mathrm{H}$ (how), yang dibuat secara jelas dan terinci 
BEduManageRs Journal

Borneo Educational Management and Research Journal, Vol.2, No.1, 2021

ISSN: 2747-0504

serta menetapkan sasaran dan target yang harus dicapai.

2) Melaksanakan rencana (do). Rencana yang telah disusun diimplementasikan secara bertahap, mulai dari skala kecil dan pembagian tugas secara merata sesuai dengan kapasitas dan kemampuan dari setiap personil.

3) Memeriksa atau meneliti hasil yang dicapai (check atau study), Memeriksa atau meneliti merujuk pada penetapan apakah pelaksanaannya berada dalam jalur, sesuai dengan rencana dan memantau kemajuan perbaikan yang direncanakan.

4) Melakukan tindakan penyesuaian bila diperlukan (action), Penyesuaian dilakukan bila dianggap perlu, yang didasarkan hasil analisis di atas.

2. Tingkat Ketercapaian Manajemen Mutu Terpadu pada SMK Negeri 7 Samarinda

Berikut ini strategi yang dilakukan dalam penerapan standar mutu di SMK Negeri 7 Samarinda:

1) Disiplin.

2) Mengikuti penataran / pelatihan / seminar.

3) Bekerjasama oleh semua stakeholder yang ada di SMK Negeri 7 Samarinda untuk mencapai visi misi.

4) Mewajibkan untuk siswa - siswi mengikuti jam tambahan bahasa inggris.

5) Mengadakan Kunjungan Kesekolah Lain (studi komperatif).

6) Mengadakan Hubungan Dengan Wali Siswa.

7) Mengadakan outbond setiap tahun dengan semua guru, staf, dan siswa siswi.

Sagala (2009) menjelaskan manajemen strategi yang diterapkan pada manajemen sekolah secara umum memiliki karakteristik, diantaranya adalah :

1) Yang di ambil bersifat strategi.
2) Penggunaan sumberdaya sekolah seefektif mungkin.

3) Berorentasi ke masa depan (jangka panjang) yaitu orientasi mutu secara berkelanjutan.

4) Sangat peduli, tanggap, dan respon dengan lingkungan eksternal.

5) Cenderung bersifat multidimensional.

Dalam melaksanakan manajemen strategi,

Berdasarkan pandangan manajemen strategi.

Selanjutnya ada beberapa hal yang perlu diperhatikan berkaitan dengan upaya meningkatkan mutu Pendidikan di SMK Negeri 7 Samarinda. Ada beberapa hal yang perlu mendapat perhatian dalam meningkatkan mutu pendidikan adalah, antara lain:

1) Peserta didik

2) Pendidik

3) Sarana dan Prasarana

4) lingkungan

3. Faktor Yang Menjadi Penghambat Dalam Implementasi Sistem Manajemen Mutu di SMK Negeri 7 Samarinda

Di SMK Negeri 7 sendiri hambatan penerapan implementasi sistem manajemen mutu ialah:

1) Masih ada beberapa guru yang gaptek teknologi.

2) Kurang antusiasnya wali siswa dalam mengisi blangko saran dan kritik yang sudah disediakan di pos satpam.

3) 3. Sering terjadinya pemadaman listrik yang dapat mengganggu pembelajaran di Lab bahasa dan Lab IT.

4) Kurangnya guru BK, sehingga guru mata pelajaran akidah akhlak merangkap sebagai guru BK.

5) Masih ada sebagaian dari pihak internal kurang komitmen dalam penjaminan mutu, hal ini dapat dilihat dari masih rendahnya inisiatif dan rasa tanggung jawab untuk melaksanakan dan memelihara serta sistem manajemen mutu yang telah ada. 
BEduManageRs Journal

Borneo Educational Management and Research Journal, Vol.2, No.1, 2021

ISSN: 2747-0504

6) Sulit mengarahkan guru yang sudah tua dalam menggunakan metode pembelajaran. Karena guru tersebut dalam proses belajar mengajar masih menggunakan metode ceramah.

7) Belum ketatnya kedisiplinan guru dalam mengajar. Contoh apabila seorang guru berhalangan hadir diluar tugas dari sekolah seharusnya guru tersebut wajib mengganti dilain waktu.

Hal penting yang perlu diperhatian dalam mengimplementasikan TQM adalah hambatanhambatan yang mungkin akan ditemui. Menurut Deming, ada "tujuh penyakit yang mematikan" sebagai hambatan dalam peningkatan kualitas, empat yang paling mematikan yaitu:

1) Kurang konstannya tujuan, sehingga organisasi terhambat untuk mengadopsi kualitas sebagai manajemen

2) Adanya pemikiran jangka pendek.

3) c.Adanya evaluasi individual yang hanya dilakukan melalui skala pertimbangan atau laporan tahunan.

4) Adanya "Job Hope" (mengharapkan jabatan).

Deming juga mengutarakan penyebab gagalnya kualitas dalam Pendidikan disebabkan oleh sumber-sumber pendidikan itu sendiri, termasuk design kurikulum, gedung sekolah/madrasah yang kurang terawat, lingkungan kerja yang buruk, sistem dan prosedur yang tidak sesuai, penjadwalan yang tidak memadai, kurangnya sumber-sumber yang penting dan pengembangan staf yang tidak memadai. Kegagalan TQM dapat juga diakibatkan oleh usaha pelaksanaan yang setengah hati dan harapan-harapan yang tidak realistis, ada pula beberapa kesalahan yang secara umum dilakukan pada saat organisasi memulai inisitaif perbaikan kualitas. Kesalahan-kesalahan tersebut antara lain:

1) Delegasi dan kepemimpinan yang tidak baik dari menejemen senior.

2) Team mania.

3) Proses penyebarluasan (deployment).

4) Menggunakan pendekatan yang terbatas dan dogmatis.

5) Harapan yang terlalu berlebihan.

6) Empowering yang bersifat premature.

Kualitas sumber daya manusia sangat erat kaitannya dengan pendidikan. Untuk itu peningkatan kualitas pendidikan merupakan suatu proses yang terintegrasi dengan proses peningkatan kualitas sumber daya manusia.

Sebelum membahas lebih jauh, ada beberapa masalah mutu Pendidikan yang diutarakan oleh Deming yang secara garis besar dikelompokkan menjadi dua hal yaitu :

1) Kendala mutu pendidikan secara umum.

2) Kendala mutu pendidikan secara khusus.

Menurut Demin mengetahui sebab kegagalan mutu dan memperbaikinya adalah tugas kunci seorang manajer. Sudah terlalu sering solusi atau orang yang tidak tepat ditugaskan untuk memecahkan masalah. Juga terlalu sering individu dipersalahkan dengan kesalahan yang bukan salah mereka. Dalam kasus - kasus sedemikian, mereka berubah menjadi frustasi ketika usaha mereka gagal. Perbedaan sederhana namun penting yang dilakukan Deming, melahirkan wawasan yang cerdas dalam mengatasi kegagalan mutu. Deming dengan sangat jelas menyatakan bahwa dalam sebagian besar kasus, ketika terjadi suatu kesalahan, staf bukan pihak yang serta - merta harus disalahkan. Namun kenyataannya, sering kali para guru menjadi kambing hitam atas kegagalan yang terjadi dalam sistem pendidikan. Di dalam literatur TQM, disebutkan bahwa pengembangan mutu yang berhasil membutuhkan komitmen abadi pihak manajemen. TQM juga menegaskan bahwa komitmen bukan sekedar mendorong usaha orang lain. Dalam istilah praktisnya, komitmen adalah kesadaran manajemen bahwa mereka adalah pihak yang 
BEduManageRs Journal

Borneo Educational Management and Research Journal, Vol.2, No.1, 2021

ISSN: 2747-0504

bertanggung jawab untuk menemukan solusi bagi sebuah kesalahan.

\section{KESIMPULAN}

Simpulan yang dapat diambil dari hasil penelitian berdasarkan faktor-faktor yang sebagaimana dipaparkan pada bab sebelumnya adalah sebagai berikut:

1. Struktur Organisasi dan Kepemimpinan Struktur organisasi pelaksana Manajemen Mutu Terpadu Melalui Pedoman di Lingkungan SMK Negeri 7 Samarinda guna tercapainya sasaran peningkatan mutu sekolah, peningkatan daya saing menuju tercapainya sekolah unggul berlangsung secara berkesinambungan telah terlaksana dan berjalan dengan baik, namun perlu dilakukan tindakan perbaikan yang disebabkan adanya tumpeng tindih terutama pada tugas tanggung jawab dengan tugas rutin sesuai job description di Tim Penjaminan Mutu.

\section{Komitmen Manajemen}

Peran serta aktif manajemen sebagai fasilitator telah dapat berperan dalam komitmen dan perilaku partisipasi langsung sesuai dengan pola kepemimpinan $M M T$ untuk memberikan motivasi pada karyawan dalam upaya melakukan inovasi penyelesaian masalah dalam tugas pekerjaan sehari-hari, meningkatkan kerjasama kelompok, membina hubungan hirarki atasan dan staff, telah dilaksanakan berdasarkan tugas dan tanggung jawabnya, namun masih perlu didukung dengan pemahaman tentang mutu terutama dalam interpretasi pada setiap tahapan langkah dan penggunaan alat bantu mutu yang sesuai dalam penyelesaian masalah.

3. Manajemen Mutu dan Keterlibatan Guru Karyawan

Secara bertahap jumlah Guru karyawan yang berperan aktif dalam kegiatan Pelaksanaan Manajemen Mutu meningkat karena pemahaman dan perilaku karyawan serta motivasi dalam memahami bahwa mutu adalah dipengaruhi oleh lingkungan kerja yang kondusif, dukungan dan perilaku manajemen dan kepemimpinan mutu, dukungan infrastruktur yang memadai, terdapat pengakuan dan penghargaan bagi karyawan, untuk menghasilkan ide-ide kreatif dan inovatif di Jurusan masing-masing dengan prinsip mutu memerlukan pelibatan dan keterlibatan seluruh karyawan bekerja sama dan peran aktif serta berkesinambungan dalam upaya peningkatan produktivitas kinerja menuju tercapainya Sekolah Unggul.

4. Motivasi Pendidik.

Dalam mengimpelementasikan MMT, motivasi pendidik dalam pelibatan dan keterlibatan pendidik secara langsung dalam upaya penyelesaian masalah dalam pekerjaan bidang masing-masing melalui Manajemen Mutu dengan ide kreatif dan inovatif telah mendukung upaya peningkatan mutu sekolah dengan adanya kebijakan Kepala Sekolah.

5. Penghargaan dan Pengakuan Prestasi

Dalam $M M T$, penghargaan dan pengakuan atas prestasi pendidik akan memberikan kontribusi signifikan sebagai motivasi yang menggerakan agar karyawan dapat menciptakan ide-ide inovasi, menyelesaikan masalah-masalah dalam pekerjaan serta perilaku nyata untuk mendukung upaya peningkatan produktivitas kinerja menuju tujuan dan sasaran terciptanya mutu sekolah secara berkesinambungan.

Pelaksanaan program pelatihan bagi pendidik baik sebagai gugus mutu dan fasilitator bagi karyawan manajemen telah dilaksanakan secara periodik dengan materi dan instruktur internal sekolah yang memiliki kualifikasi dan sertifikat kompetensi bidang mutu serta untuk penilai dengan melibatkan provider ekternal. 
BEduManageRs Journal

Borneo Educational Management and Research Journal, Vol.2, No.1, 2021

ISSN: 2747-0504

\section{DAFTAR PUSTAKA}

Abu. Ahmadi. Nur , Uhbiyati 1991 , Ilmu Pendidikan Islam, Rineka Cipta, Jakarta, 140

Al-Qahtani, N., Alshehri, S., and Abdul-Aziz, A. (2015) The Impact Of Total Quality Management On Organizational Performance. [Online] Available from : http://www.iiste

.org/journals/indrx.php/EJBM/article/view /27529 [Accessed 20 October 2017].

Amtu, Onisimus. 2011. Manajemen Pendidikan di Era Otonomi Daerah.Bandung: Alfabeta.

Belwati, T. and Zuhairi, A. (2007) The partice of a quality assurance system in open and distance learning : A case study at Uiversitas Terbuka Indonesia (The Indonesia Open University). [Online] Available from: http://www.irrodl.org/index.php/irrodl/arti cle/view/340/774 [Accessed 20 October 2017]

BPS. "Laporan Bulanan Data Sosial Ekonomi", Edisi 45. Katalog BPS: 91199017 (Februari 2014). http://www.bps.go.iddownload fileIP Feb ruari 2014. pdf(akses 24 Septemer 2014).

Burhanuddin Dkk, Op. Cit: 86

Burnham, John West. 1997. Managing Quality Schools: Effective Strategies for Qualitybased School Improvement. 2nd Edition. London: Pearson Education.

Depdiknas. 2001. Manajemen Peningkatan Mutu Berbasis Sekolah (Buku 1). Jakarta: Depdiknas

Dirawat, Pengantar Kepemimpinan Pendidikan, Usaha Nasional, Surabaya, 1983: 132

Djumhur, Moh. Surya, Bimbingan Dan Penyuluhan Di Sekolah, CV. Ilmu, Bandung, 1975: 115
Fathoni, Abdurrahman, 2006, Organisasi dan Manajemen Sumber Daya Manusia, Jakarta: PT. Rineka Cipta

Fandy, Tjiptono \& Anastasia, Diana, (2010). Total Quality Management, Edisi Revisi, Yogyakarta: Andi Offset.

Fuentes, C., Benavent, F., Moreno, M., Cruz, T., and Del Van, M. (2000) Analysis of the implementation of ISO 9000 quality assurance system. Work study, 49(6), 229241.

Garwe, E. (2012) Quality assurance in higher education in Zimbabwe. [Online] Available from: http://www. Aabri.com/manuscripts/131745.pdf [Accessed 20 October 2017]

Haidar Putra Daulay, Pendidikan Islam Dalam Sistem Pendidikan Nasional di Indonesia, Prenada Media, Jakarta, 2004: 82

Hardjosoedarmo, Soewarso. 2002. "Total uality Management”. Yogyakarta: Andi.

H. A. R Tilaar Op cit: 187

Jam Jami, M. Syukri, dan Wahyudi, 2013. "implementasi Manajemen Mutu Terpadu (MMT) di SD Negeri 03 Muara Pawan Kabupaten Ketapang "Jurnal. Pontianak: Program magister Administrasi Pendidikan FKIP Universitas Tanjungpura http://download.potalgaruda.org/article $=11$ $1862 \&$ val $=2338$. (akses 28 September 2014)

Kementrian Koordinator Bidang Kesejahtraan Rakyat, "Jumlah SMK Indonesia". Menkokesra.go.id (September 2009). OSMK.xls (akses 21 September 2014).

Kusmana,

Suherlin.2009.http://suherlicenter.blogspot .com/2009/06.manajemen-strategikdalammengelola. Html

Liao, S.H., Chang, W.J., and Wu, C.C (2010),"Exploring QTM-Innovation Relationship in Continuing Education: A 
BEduManageRs Journal

Borneo Educational Management and Research Journal, Vol.2, No.1, 2021

ISSN: 2747-0504

System Architecture and Propositions",

Total Quality Management, Vol.21 No.

11, pp. 1121-1339

http://65.54.133.26/Journal/5060/total-

quality-manag-bus-excell-total- qualitymanagement-\&-business_excellence(akses 21 September 2014)

Magdalena, Nonie dan Imelda Junita. (Maret 2014) "Managing Service in Education Through Continuousassement of the Performance quality in Education". The 2nd IBEA-Internasional Conference on Business, Economicks and Accounting. http://www.caalinteduorg.com/ibea2/ibea2_proc/051Mar-Nonie_M\&Imelda_J-

Managing_Service_in_Education.pdf (akses 21 September 2014).

Malau, Srihandriatmo dan Rendy Sadikin, "Nasib Dunia Pendidikan Indonesia Tak Semulus Pertumbuhan ekonomi”. Tribun News ( 2 dunia-pendidikan-indonesia-tak-semuluspertumbuhan-ekonomi (akses 21 September 2014).

Miles,M.B, Huberman,A.M, dan Saldana,J. 2014. Qualitative Data Analysis, A Methods Sourcebook, Edition 3. USA: Sage Publications. Terjemahan Tjetjep Rohindi Rohidi, UI-Press

Muhtaram, Aceng. 2001. Strategi Penerapan Manajemen Mutu dalam Sistem Pendidikan Nasional (Kajian ke Arah Penemuan Model). Jakarta: Universitas Pendidikan Indonesia. http://file,upi.edu/Direktori/FIP/JUR._AD MINISTRAS_PENDIDIKAN/195706161 986011-

ACENG_MUHTARAM_MIRFANI/Pener apan-Manajemen-Mutu_by-

AM.Mirfani.pdf (akses 1 Oktober 2014)
M.N. Nasution. 2010. Manajemen Mutu Terpadu. Jakarta : Ghalia Indonesia.

N. A. Ametembun, Supervisi Pendidikan Penuntun Bagi Para Kepala Sekolah dan Guru-Guru, Suri, Bandung, 1981: 103

Naiyah, 2014 "Penerapan Manajemen Mutu Terpadu (MMT) di SMP N Belik Kabupaten Pemalang. Tesis. Yogyakarta: Program Pasca Sarjana Universitasn Ahmad Dahlan Yogyakarta. http://pascamp.uad.ac.id/wpcontent/uploads/ABSTRAK-Naiyah.pdf (akses 28 September 2014)

Piet. A. Sehartian, Prinsip Teknik Supervisi Pendidikan, Usaha Nasional, Surabaya, 1981: 108

Robbins, P. Stephen dan Timothy A. Judge. 2008. Perilaku Organisasi (Organizational Behavior). Edisi Kedua Belas Buku 1. Jakarta : Salemba Empat. Hal 101.

Ryan, T. (2015) Quality assurance in higher education: A review of literature. Higher Learning Research Communications, 5(4), 2157-6254.

Sagala.2009. Manajemen Strategit dalam Peningkatan Mutu Pendidikan.Bandung : Alfabeta.

Salis,Edwar.2006. Manajemen Mutu Terpadu Pendidikan.Jogjakarta:IRCiSoD.hal 105.

Shams, S.(2017) Transnational education and total quality management: a stakeholdercenteredmodel. Journal of Management Development, 36 (3), 376-389.

Syaiful Bahri Djamarah, Guru dan Anak Didik Dalam Interaksi Edukatif, Rineka Cipta, Jakarta, 2000: 52

Sa'ud, Udin S. 2004. Manajemen Mutu Terpadu (Total Quality Management) dalam Rangka Sukses UAN di Madrasah. Handout Seminar Sehari Pengembangan Madrasah dan Pondok Pesantren di 
BEduManageRs Journal

Borneo Educational Management and Research Journal, Vol.2, No.1, 2021

ISSN: 2747-0504

Provinsi Banten Serang, 25 Maret 2004.

Jakarta: Universitas Pendidikan Indonesia.

Sudjana, 2004, Manajemen Program Pendidikan;

Untuk Pendidikan Nonformal dan

Pengembangan Sumber Daya Manusia, Bandung: Falah Production.

Situngkir, Sahata Marlen. 2009 "Pengaruh Penerapan Manajemen Mutu Terpadu Terhadap Kualitas Sumber Daya Manusia di Rumahh Tahanan Negara Klas I Medan“.Sekolah Pascasarjana Universitas Sumatera Utara. http://repository.usu.ac.id/bitsream/12345 6789/19414/7/Cover.pdf

Undang - Undang R.I No. 20 Tahun 2003 Tentang Sisdiknas \& Peraturan Pemerintah R.I No. 47 Tahun 2008 (Bandung: Citra Umbara, 2006), hlm. 77

Usman, Husanini. 2014. Manajemen, Teori, Praktik, dan Riset Pendidikan (Edisi ke 4). Jakarta: Bumi Aksara.

Widodo, Suparno Eko. 2011. Manajemen Mutu Pendidikan. Jakarta: Ardadizya Jaya.

Wijaya, David.2008. Implementasi Manajemen Mutu Terpadu dalam Penyelanggaraaan
Pendidikan di Sekolah. Jurnal Pendidikan Penabur. No. 10/tahun ke-7/Juni 2008. http://www.bpkpenabur.or.id/files/Hal.\%2 084-

94\%20Implementasi\%20Manajemen\%20

Mutu.pdf(akses 1 Oktober 2014)

Woodhouse, D. and Stella, A. (2011). Regulation and Quality assurance of higher education institutions in Australia. [Online] Available from: http://ieeexplore.ieee.org/document/62211 46/?reload=true [Accessed 20 October 2017]

Zahroh, Aminatul. 2014. Total Quality Management: Teori \& Praktik Manajemen untuk mendongkrak Mutu Pendidikan. Yogyakarta: Ar-Ruzz Media.

Zamroni, Paradigma Pendidikan Masa Depan, BIGRAF Publishing, Yogyakarta, 2001: 51

Zehir, C., Ertosun, O., Zehir, S., and Muceldilli, B. (2012) Total Quality Management practices effects on quality performances. Procedia-social and Behavioral Sciences, 41(12), 273-280. 